\title{
DIE PYNERVARING EN DIE BERAMING DAARVAN BY PASIËNTE MET KARSINOOM
}

\author{
N.C. van Wyk
}

\begin{abstract}
SUMMARY

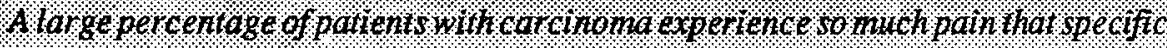
nuwhing interventions are inperathe Approprinte interventons ore possible only

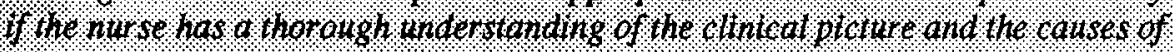
poin in patients with carcinomo. She should also be cognisant of the assessment: possibitities tegarditis the dentiftcation of the notwe and intensity of their pain.
\end{abstract}

\section{SAMEVATTING:}

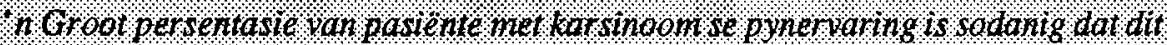

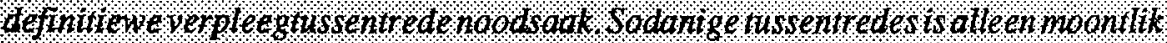
Wonneer die verples gkundige in grondige kennis het van die klintese beetd en

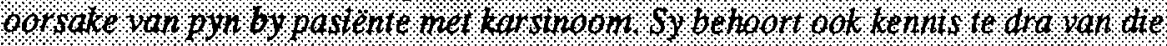
beramingsmo ontlikhede ter identifisering van die oard en intentieit van die ijusentring:

\section{INLEIDING}

Pyn word algemeen geassosieer met karsinoom. Dit is dan ook dikwels die teenwoordigheid van pyn by persone met karsinoom wat daartoe bydra dat lyding algemeen aan karsinoom gekoppel word. Lipman (1980:39) en Foley (1985:93) is van mening dat die algemeenste vrees wat aan karsinoom verbind word, juis die vrees vir pyn is. Muller en Pelczynski (1982:53) bevestig dit deur daarop te wys dat die vrees vir pyn en die dood die algemene vrese van die pasiënt met karsinoom is. Massie en Holland (1987:243) koppel die vrees vir pyn en die dood deur die stelling dat die primêre kommer van 'n pasiënt met karsinoom sentreer om die vrees vir 'n pynlike dood.

Pyn word in die algemeen beskou as ' $n$ waarskuwingsteken van veranderinge in die liggaam. Steinbach, soos aangehaal deur Jacox, definieer pyn dan ook as "an abstract concept which refers to (1) a personal, private sensation of hurt; (2) a harmful stimulus which signals current or impending tissue damage; (3) a pattern of responses which operate to protect the organism from harm" (Jacox 1979:895). By die pasiënt met karsinoom dien pyn egter maar net in enkele gevalle as so 'n kortstondige waarskuwingsteken. Die pyn wat deur 'n pasiënt met karsinoom ervaar word, is veel eerder 'n chroniese, progressiewe destruktiewe ervaring (Dugan 1984:277). Coyle (1987:259) stel dit dan ook dat die pyn wat 'n pasiënt met karsinoom ervaar nie net die gevolg is van die weefselskade wat deur die destruktiewe siektetoestand veroorsaak is nie, maar dat die psigososiale gevolge van die veelvuldige verliese wat die pasiënt ervaar, tesame met die moontlikheid van dood bydra tot die ervaring van pyn. Pyn van so 'n intensiteit en duur affekteer volgens Daut en Cleeland (1982: 1913) die kwaliteit van die pasiënt se lewe, sy wil om te lewe en sy samewerking in die behandeling van sy siektetoestand.

Daar word algemeen aanvaar dat pyn 'n individuele ervaring is (Holmes 1987:51, Bagley et.al. 1982:191). Donovan (1982:713) bevestig dit deur die stelling dat pyn 'n komplekse fenomeen is waarby fisiologiese, psigologiese, sosiale, kulturele en religieuse veranderlikes betrokke is. Hierdie faktore bepaal die ervaring wat die pasiënt as pyn beleef. Bagley en sy kollegas (1982:191) is van mening dat pyn 'n subjektiewe ervaring en multidimensionele konsep is wat tot uiting kom op verskeie maniere. Young onderskryf om hierdie rede die definisie van pyn soos geformuleer deur McCaffery: "Pain is whatever the experiencing person says it is and exists whenever he says it does" (Young 1977:655).

\section{DOELSTELLING VAN DIE STUDIE}

Die doel van die studie is om 'n teoretiese perspektief van die pynervaring van pasiënte met karsinoom te verkry. Daar is in die verlede en daar word tans geweldig baie navorsing oor sekere aspekte van pynervaring gedoen. Die publikasies wat hieruit voortspruit handel dan oor die aspekte wat nagevors is. ' $n$ Gefragmenteerde beeld van pynervaring word dus gegee. Met hierdie studie is gepoog om uit die bestaande literatuur ' $n$ samevattende oorsig oor die totale spektrum van pynervaring te gee. Daar is verder gepoog om dit vanuit 'n verpleegkundige perspektief met die oog op die verpleegkundige beraming van pasiënte met karsinoom wat pyn ervaar te doen.

\section{METODOLOGIE VAN DIE NAVORSING}

'n Intensiewe omvattende literatuurstudie oor die pynervaring van pasiënte met karsinoom is gedoen. In die studie is daar veral klem gelê op die oorsake van pyn by pasiënte met karsinoom. Die oorsake van pyn is bepalende faktore in die beplanning van verpleegtussentredes met die oog op pynverligting.

\section{LITERATUUROORSIG}

Voorkomssyfer van pyn by pasiënte met karsinoom

Alle pasiënte met karsinoom ervaar nie noodwendig pyn nie (Burns 1982:217). Volgens Dugan is dit moontlik dat karsinoom in die totale siekteverloop nooit pyn sal veroorsaak nie. Die moontlikheid dat karsinoom pyn tot gevolg sal hê word volgens haar gekoppel aan die geneigdheid van spesifieke tipes karsinoom om na pynsensitiewe weefsel te metastaseer (Dugan 1984:285). Foley (1985:84) sluit hierby aan met sy gevolgtrekking dat die voorkoms van pyn toeneem met die verloop van karsinoom. Volgens Hillier (1987:1645) ervaar vyf persent van pasiënte met karsinoom pyn met diagnosering van die karsinoom terwyl 60 persent van pasiënte met karsinoom pyn ervaar wanneer hulle sterf.

Lipman (1980:39) maak die stelling, wat hy grond op sy jarelange ervaring met pasiënte met karsinoom, dat erge chroniese pyn slegs by 20 persent van pasiënte wat sterf as gevolg van karsinoom, voorkom. Steele, soos aangehaal deur Anderson (1982:33) is egter van mening dat 60 persent van haar pasiënte wat versorg word in die Saint Christopher's Hospice in Engeland pyn ervaar. Sy gee egter toe dat dit varieer tussen matige tot erge pyn. Foley, soos aangehaal deur Cleeland (1984:2636) het in 'n ondersoek wat gedoen is in die Memorial Sloan Kettering Cancer Center, gevind dat 29 persent van die gehospitaliseerde pasiënte tot so 'n mate pyn ervaar het dat hulle analgetiese middels benodig het. In ' $n$ verdere studie van Foley 
waartydens onderhoude met 397 pasiënte gevoer is, is bevind dat 38 persent van hierdie groep persone beduidende pyn ervaar het (Daut en Cleeland 1982:1913).

Met betrekking tot die voorkomssyfer van pyn by vroue met karsinoom van die mammae het Daut en Cleeland (1982:1914) in 'n ondersoek wat 289 vroue ingesluit het, bevind dat 64 persent van die vroue met metastases pyn ervaar het terwyl 40 persent van die vroue wat nie metastases gehad het nie, pyn ervaar het. Hulle het verder bevind dat 34 persent van hierdie vroue die intensiteit van die pyn wat hulle ervaar het op 'n skaal van nul tot 10 as vyf en hoër gegradeer het. 'n Verdere bevinding was dat 39 persent van die vroue in hierdie ondersoek pyn as 'n vroeë teken van hulle karsinoom geidentifiseer het (Daut \& Cleeland 1982:1916). Spiegel en Bloom het oor 'n periode van een jaar die pyn ervaring van 86 vroue met metastatiese karsinoom van die mammae geëvalueer. Hulle het gevind dat 44 persent van die groep vroue geen pyn ervaar het nie. Bykans 'n derde van die vroue (30 persent) het matige pyn ervaar. Op'n skaal van nul tot 10 was die gemiddelde gradering van die intensiteit van die pyn wat dié vroue ervaar het 2,2 (Spiegel en Bloom 1982:341). Foley het in 'n opname wat een week geduur het, gevind dat 2 persent van die vroue met karsinoom van die mammae wat in die Memorial Sloan Kettering Cancer Center gehospitaliseer was tot so 'n mate pyn ervaar het, dat hulle analgetiese middels benodig het. Vroue met post-operatiewe pyn is nie in die studie ingesluit nie (Cleeland 1984:2636).

\section{Kliniese beeld van pyn by pasiënte met karsinoom}

Hoewel chroniese pyn meer algemeen met karsinoom geassosieer word, mag pasiënte met karsinoom in sekere situasies ook akute pyn ervaar. Voorbeelde van akute pyn word deur Burns (1982:217) aangegee as pyn wat post-operatief ervaar word, sowel as pyn wat as simptoom in die vroeë stadium van karsinoom voorkom. Akute sowel as chroniese pyn mag dus in die siekteverloop van karsinoom voorkom, met akute pyn meer algemeen in die aanvang van siekteverloop en chroniese pyn meer algemeen in die latere fase van siekteverloop.

'n Onderskeid tussen akute en chroniese pyn is in die eerste instansie in die tydsduur daarvan geleë. Meinhart en McCaffery stel dit dat akute pyn vir 'n tydperk van minder as ses maande duur (Campen O'Sullivan 1987:593). Hierteenoor is chroniese pyn volgens Ruoff en Beery (1985:92) pyn wat langer as ses maande ervaar word. 'n Verdere onderskeid lê in die aanvang daarvan. Akute pyn is 'n skielike, intense, gelokaliseerde pyn, terwyl die aanvang van chroniese pyn nie-spesifiek is. Chroniese pyn kan selfs as 'n akute pyn begin (Burns 1982:217). Akute pyn ontlok in die pasiënt response van die simpatiese senuweestelsel, terwyl chroniese pyn verstadiging, kenmerkend van stimulasie van die parasimpatiese senuweestelsel tot gevolg het (Van Wyk 1987:226).

Chroniese pyn, soos wat ervaar word met 'n gevorderde karsinoom, is 'n meer komplekse ervaring as akute pyn. Dit is omdat chroniese pyn voortdurend teenwoordig is en erge implikasies vir die persoon kan inhou. Baines maak die stelling dat chroniese pyn, anders as akute pyn, 'n situasie eerder as 'n enkel gebeurtenis is. Voorts sê hy dat die einde van chroniese pyn nie voorspelbaar is nie, dat die pyn voortdurend vererger word eerder as dat dit verminder en dat dit die pasiënt se totale aandagspan in beslag neem en hom dus isoleer van ander mense (Moseley 1985:428). Wainwright (1985:59) sluit hierby aan en is van mening dat chroniese pyn demoraliserend is en daarom die vrou se onafhanklikheid bedreig en gevolglik haar menswaardigheid verminder. Volgens Booker (1982:48) ontwikkel die pasiënt wat voortdurend chroniese pyn ervaar 'n pynpersoonlikheid. Hierdie pasiënte ervaar 'n gevoel van hulpeloosheid en waardeloosheid terwyl hulle tegelyk ook angstig, gespanne en hipersensitief voorkom.

Chroniese pyn kan volgens Lipman (1980:40) drie-dimensioneel beskryf word. Hierdie dimensies is fisiek, psigologies en sosiaal. Die fisieke komponent kan varieer sodat pyn by tye minder erg en by tye erger is soos wanneer beenmetastases voorkom. Die psigologiese reaksie op fisieke pyn, wat dikwels angs en depressie is, is die psigologiese komponent van pyn, terwyl die sosiale komponent die gevolglike isolasie van die pasiënt is wat voortspruit uit die psigologiese reaksies.

Die pyn wat 'n pasiënt met karsinoom ervaar kan ook in ander kategorieë as net akuut en chronies verdeel word. Hierdie kategorieë hou verband met die plek van oorsprong van die pyn. Drie kategorieë word onderskei, naamlik somatiese pyn, viserale pyn en neurogene pyn (Payne 1987:153). Somatiese pyn word ervaar as 'n goed gelokaliseerde kloppende pyn. Dit kom voor in die geval van metastases na beenweefsel soos in die geval van karsinoom van die mammae. Viserale pyn kom voor met infiltrasie van abdominale en torakale organe deur primêre of metastatiese tumorgroei en word ervaar as diep, swak gelokaliseerde drukkende pyn. Dit mag ook as verwysde pyn in oppervlakkige weefsel ervaar word (Payne 1987:153). Neurogene pyn is die gevolg van beskadiging van perifêre en/of sentrale senuvesels en word ervaar as 'n dowwe, voortdurende, somtyds drukkend en somtyds brandende pyn (Payne 1987:154). 'n Voorbeeld van neurogene pyn by die vrou met karsinoom van die mammae, is die pyn wat ervaar word met bragiale pleksopatie (Payne en Foley 1986:329, Kori et.al. 1981:45).

\section{Patofisiologie van pyn by pasiënte met karsinoom}

Volgens Dugan (1984:277) is die hoof oorsake van die pyn wat 'n pasiënt met karsinoom ervaar tewyte aan die tumor en gevolglike verspreiding sowel as die effekte van die behandeling van die karsinoom. Die grootste oorsaak van pyn is egter die onkologiese proses. Volgens Foley (1985:86) is dit verantwoordelik vir 78 persent van die pyn wat pasiënte in die Memorial Sloan-Kettering Cancer Center ervaar. In 'n opname het Daut en Cleeland (1982:1916) bevind dat 56 persent van pasiënte met metastatiese karsinoom en 17 persent van pasiënte met nie-metastatiese karsinoom pyn ervaar het as gevolg van hul karsinoom. Die oorsake van pyn wat direk gekoppel kan word aan die onkologiese proses is;

- infiltrasie van beenweefsel deur die tumor,

- drukking op en infiltrasie van senuvesels,

- infiltrasie van bloedvate,

- swelling van strukture wat deur fascia en ander pynsensitiewe strukture omring word,

- infeksie en ulserasie van slymvlies en ander pynsensitiewe strukture, en

- obstruksie van strukture soos ureters, gastroïntestinale kanaal en tragea (Burns 1982:217, Dugan 1984:287, Perkin 1987:1635, Foley 1987:170, Payne 1987:156, Muller en Pelczynski 1982:53).

Die behandeling van karsinoom is verantwoordelik vir die pyn van 19 persent van alle pynsituasies wat gehospitaliseerde pasiënte ervaar en vir 25 persent van alle pynsituasies wat pasiënte ervaar wat buite die hospitaal behandel word (Foley 1985:86). Die oorsake van pyn wat direk gekoppel kan word aan die behandelingsproses is

\section{- post-operatiewe pyn,}

- post-chemoterapie pyn wat perifêre neuropatie en aseptiese nekrose van beenweefsel insluit, en

- post-radioterapie pyn wat miëlopatie, fibrose van die bragiale pleksus en lumbosakrale pleksus insluit (Foley 1987:170, Dugan 1984:287).

Pasiënte met karsinoom ervaar ook soms pyn wat nie direk verbind kan word aan die onkologiese proses of die behandeling van die pasiënt nie. Volgens Foley (1985:86) ervaar drie persent van gehospitaliseerde pasiënte en 10 persent $v$ an pasiënte wat buite die hospitaal behandel word pyn wat nie direk gekoppel kan word aan karsinoom of die behandeling daarvan nie. Oorsake van hierdie pyn is;

- konstipasie,

- ulkusse,

- spierspasmas, en

- absesse (Burns 1982:220).

Volgens Foley kan die pyn wat 'n pasiënt met 
karsinoom ervaar, geklassifiseer word volgens die oorsake daarvan. Die klassifikasie is soos volg;

- akute karsinoom-verwante pyn

a) geassosieer met die diagnose van karsinoom

b) geassosieer met die behandeling van karsinoom

- chroniese karsinoom-verwante pyn

a) geassosieer met die progressering van die karsinoom

b) geassosieer met die behandeling van die karsinoom,

- reeds bestaande chroniese pyn en karsinoom-verwante pyn, en

- karsinoom-verwante pyn in die terminale fase van siekteverloop (Foley 1985:85)

Sensoriese reseptore (in Engels nociceptors) wat sensitief is vir skadelike (in Engels noxious) of potensieel skadelike stimuli word gevind in die vel, spier- en bindweefsel sowel as in die torakale en abdominale organe (Payne 1987:155). Hierdie reseptore is nie-spesifiek en sal op alle skadelike stimuli, hetsy meganies, termies of chemies reageer (Davis 1985:36). 'n Voorbeeld van meganiese stimuli wat karsinoom-verwant is, is tumor infiltrasie, terwyl beenmetastases ' voorbeeld van chemiese stimuli is (Foley 1985:86). In die gastrointestinale kanaal word hierdie reseptore by uitstek gestimuleer deur oormatige distensie of kontraksie van die dermkanaal sowel as torsie van die mesenterium (Payne 1987:157). Volgens Bonica is metastatiese infiltrasie van been- en longweefsel sowel as die abdominale organe 'n algemene oorsaak van pyn (Payne 1987:156).

$\mathrm{Na}$ aktivering stuur die reseptore impulse via $\mathrm{C}$-vesels en A-deltavesels na die dorsale horing van die spinaalkoord. Die C-vesels is dun ongemiëliniseerde vesels en gelei om hierdie rede pynimpulse baie stadig. Hierteenoor is die A-deltavesels, gemiëliniseerd en gelei dus die impulse, hoewel dun, heelwat vinniger. Vanweë die geleiding van impulse deur beide tipes vesels ervaar die pasiënt eers 'n skerp gelokaliseerde sensasie wat gevolg word deur 'n dowwe, kloppende, diffuse pyngevoel. Dit staan ook bekend as vinnige en stadige, of eerste en tweede pyn (Meij en Meyer 1979:13.3).

Die afferente senuvesels betrokke by die geleiding van pynimpulse vorm sinapse in die dorsale horing van die spinaalkoord. Die A-deltavesels vorm hul sinapse in lamina I, II en III van die dorsale horing en die C-vesels hoofsaaklik in lamina II. Lamina II en III vorm die substantia gelatinosa (Payne 1987:158). Die substantia gelatinosa is besonder betrokke by pynimpuls-geleiding omdat beide die
A-delta en C-vesels hier sinapse vorm. Die substantia gelatinosa is egter ook betrokke by geleiding van ander tipes impulse. Groter afferente senuvesels as die A-delta en C-vesels vorm hier sinapse. Dit maak die afsluiting van pynimpulse moontlik. Wanneer die geleiding van impulse in die groter senuvesels gestimuleer word, aktiveer dit die substantia gelatinosa tot so ' $n$ mate dat dit die geleiding $v$ an enige ander impulse, insluitend pynimpulse teenstaan (Davis 1985:37).

Die substantia gelatinosa funksioneer dus soos 'n 'hek' wat by tye 'oop' is en impulse deurlaat en by tye impulse afsluit. Geleiding via vesels wat klein in deursnee is, hou die 'hek oop' en pynimpulse kan dus gelei word terwyl geleiding via vesels wat groter is in deursnee die 'hek sluit' sodat pynimpulse nie gelei word nie (Snyder 1986:309). So sal massering van 'n pynlike area, waarvandaan die impulse met groter afferente vesels gelei word na die substantia gelatinosa die 'hek sluit' sodat die pynimpulse nie gelei word nie. Voortdurende pynimpulse, hoewel van 'n lae intensiteit, word egter as pyn ervaar, want dit word gelei deur klein afferente vesels wat die "hek oophou' en die impulse word dus verder gelei (Davis 1985:37).

Die afferente senuvesels, wat pynimpulse gelei dra die impulse oor aan die T-selle, wat die eerste oordragselle in die dorsale horing is (Snyder 1986:309). Die impulse word in drie bane na die brein gelei, naamlik die spinotalamiese, sinoservikale en spinoretikulêre bane (Payne 1987:158). In die brein kan die impulse die talamus aktiveer sodat die pasiënt bewus word van die pyn hoewel sy dit nie kan lokaliseer nie. Die somatosensoriese korteks van die serebrum moet eers geaktiveer word voordat die pasiënt die pyn sal kan lokaliseer. Pynimpulse kan direk van die spinaalkoord na die talamus en somatosensoriese korteks gelei word (Snyder 1986:310), terwyl pynimpulse ook via die retikulêre stelsel na die talamus en ander dele van die brein gelei kan word. Geleiding na die limbiese stelsel word geassosieer met die affektiewe aspekte van die pynervaring.

Afgesien van die hek-beheer meganisme in die substantia gelatinosa wat die geleiding van pynimpulse kan beheer of beïnvloed, kan die geleiding van impulse in die spinotalamiese bane beheer word deur die vrystelling van serotonien. Volgens Booker (1982:49) inhibeer serotonien die oordrag van impulse terwyl Payne (1987:161) bloot sê dat dit die aktiwiteit in die spinotalamiese baan moduleer. Serotonien word volgens Booker (1982:49) onder andere geproduseer in die sentrale senuweestelsel. Serotonien word vrygestel wanneer sekere endogene pynonderdrukkende bane gestimuleer word. Een van hierdie bane begin in die midbrein vanwaar dit verloop na die medulla en dan na die dorsale horing van die spinaalkoord. 'n Tweede baan verloop van die pons na die dorsale horing van die spinaalkoord (Payne 1987:160). Volgens Basbaum en Fields kan hierdie bane geaktiveer word deur verskeie fisiologiese en eksperimentele stimuli, insluitend stres (Payne 1987:161).

In die sentrale senuweestelsel word ook endogene opioïedpeptiede aangetref. Hierdie groep peptiede oefen bepaalde beheer uit oor die geleiding van pynimpulse. Voorbeelde van endogene opioîedpeptiede is enkefalien, B-endorfien en dinorfien (Payne 1987:161). Volgens Snyder (1986:311) word endorfien dikwels as groepnaam vir die opioïedpeptiede gebruik. Endorfien word deur Wilson en Elmassian (1981:722) beskryf as opioïedpeptiede wat die potensiaal het om veranderinge teweeg te bring in pynpersepsie, gemoedstoestand, asemhaling en die vrystelling van hormone van die hipofise. Van die opioïedpeptiede in die algemeen sê West (1981:50) dat ditpynpersepsie verander eerder as om pyn te voorkom. Meyer (1979:57.9) is van mening dat die opioïedpeptiede hulle funksie verrig deur self as neuro-oordragstowwe op te tree of deur die vrystelling en funksie van ander oordragstowwe te moduleer. West (1981:50) steun hierdie siening deur die mening te huldig dat endorfien die vrystelling van P-substansie, ' $n$ ander peptied en oordragstof wat by die eerste sinaps in die afferente bane in die spinaalkoord voorkom, te inhibeer. Davis (1985:37) is van mening dat enkefalien ook die vrystelling van P-substansie inhibeer. Wilson en Elmassian (1981:722) beskryf die funksie van endorfien breër. Hulle is van mening dat endorfien die oordrag $v$ an pynimpulse op verskeie plekke in die sentrale senuweestelsel inhibeer. In aansluiting hierby is Payne (1987:162) van mening dat die opioïedpeptiede pynverligting teweegbring deurdat hulle verbind met spesifieke reseptore in die serebrale korteks, breinstam en spinaalkoord. Soos wat afgelei kan word uit die funksies van die opioiedpeptiede word hulle aangetref in die sentrale senuweestelsel (Payne 1987:162, Snyder 1986:311, Davis 1985:37, West 1981:50, Wilson en Elmassian 1981:722). Hierdie peptiede word egter ook buite die sentrale senuweestelsel aangetref (Wilson en Elmassian 1981:722). Meyer is voorts van mening dat die endorfiene ekstraserebraal gesintetiseer word en wel in die wande van die spysverteringskanaal (Meyer 1979:57.9)

\section{Beraming van pyn by pasiënte met karsinoom}

Die eerste stap in die behandeling van 'n pasiënt met pyn is die beraming daarvan (Anderson 1982:34). Volgens Moseley (1985:429) lê die groot uitdaging daarin om die probleem vroegtydig op te spoor en te beraam. Die beraming van 'n pasiënt met pyn is egter vanweë die subjektiewe aard van pyn, 'n baie moeilike proses. 'n Faktor wat die proses kan vergemaklik is 'n vertrouensverhouding tussen die pasiënt en die persoon wat die beraming doen (Foley 1985:84).

Omdat pyn 'n subjektiewe ervaring is, speel verskeie faktore 'n rol in die pasiënt se 
persepsie van haar pyn. Volgens Spiegel en Bloom (1983:342) sal die betekenis wat die pasiënt aan die pyn heg 'n belangrike faktor wees. Die pyn wat 'n pasiënt tydens behandeling ervaar kan vir die een pasiënt dui op die buitengewone effektiwiteit van die behandeling en vir 'n volgende pasiënt dat die behandeling oneffektief is. Nie slegs hierdie pasiënte se persepsie nie, maar ook hul reaksie op die pyn sal verskil. Cummings verdeel die faktore wat pynpersepsie kan beïnloed in fisieke, psigologiese en sosiokulturele faktore. Onder die fisieke faktore beskryf sy moegheid, swak liggaamshouding, spierspanning en geneesmiddel-afh anklikheid. Die psigologiese faktore is depressie, 'n gebrek aan inligting en ander stresvolle gebeure, terwyl die sosiokulturele faktore kulturele en gesinsfaktore insluit (Cummings 1981:60). Twycross, soos aangehaal deur Dugan is van mening dat faktore soos slaap en rus ook pynpersepsie kan beïnvloed (Dugan 1984:287).

Wanneer die voorafgaande, naamlik dat pyn 'n subjektiewe ervaring is en dat pynpersepsie van indiwidu tot indiwidu verskil en in een indiwidu van tyd tot tyd verskil, aanvaar word, beklemtoon dit die belang van die pasiënt se betrokkenheid in die beraming van pyn. Holmes (1987:51) stel dit dat pyn nie objektief gemeet kan word nie, daarom kan alleen die pasiënt sê of sy pyn het en wat die intensiteit daarvan is. Donovan (1982:715) sluit hierby aan en sê dat indien die pyn wat 'n pasiënt met karsinoom ervaar beoordeel moet word op die teenwoordigheid $v$ an ' $n$ definitiewe fisieke oorsaak, 'n groot persentasie pasiënte hanteer sal word asof hulle fiktiewe pyn ervaar. Sy grond haar stelling daarop dat algemeen aanvaar word dat pasiënte met beenmetastases pyn ervaar, maar dat 60 persent van die beendigtheid deur die metastases geaffekteer moet wees alvorens dit op X-strale sigbaar is, terwyl die letsel dan reeds lankal pyn kan veroorsaak. Foley $(1985: 85)$ is verder van mening dat daar baie min objektiewe tekens is wat daarop dui dat 'n pasiënt pyn ervaar, maar dat dit nog moeiliker is om die intensiteit van pyn volgens objektiewe tekens alleen te bepaal. Ter stawing hiervan wys Donovan daarop dat die tekens as gevolg van simpatiese stimulasie geassosieer met akute pyn verdwyn wanneer die pyn chronies raak. Tekens van parasimpatiese stimulasie, wat minder dramaties en moeiliker waarneembaar is, word dan aangetref (Donovan 1982:716).

Fordyce is egter van mening dat pyn nie net beraam kan word in terme van wat die pasiënt verbaliseer nie. Die redes wat hiervoor aangegee word is eerstens dat die pasiënt te min kennis het om die veranderinge in haar liggaam te interpreteer en te rapporteer en tweedens dat die verbale en nie-verbale uiting van pyn kan verskil en dat die verbale uiting dan nie die nie-verbale uiting behoort te oorskadu nie (Jacox 1979:895, 896). Volgens Muller en Pelczynski (1982:53) gee pasiënte met chroniese pyn nie noodwendig uitdrukking aan hulle pyn nie. Hulle ontwikkel eerder meganismes om die intensiteit daarvan te verminder. Jacox het in 'n opnamestudie wat 102 pasiënte ingesluit het, waarvan 'n groep metastatiese karsinoom gehad het, gevind dat 70 persent van die persone nie graag hulle pyn met ander persone wou bespreek nie. Redes wat hulle hiervoor gegee het, het daarop neergekom dat hulle glo dat ander persone nie graag van hulle pyn wou hoor nie. Twee-derdes van die groep het gesê dat wanneer hulle pyn ervaar hulle probeer om so op te tree dat ander dit nie merk nie. Die rede hiervoor is dat pyn gestigmatiseer word en dat daar algemeen van mense verwag word om pyn te kan verduur (Jacox 1979:896 en 897). Daar kan dus in die beraming van pyn nie net op die pasiënt se interpretasie en verbalisering gesteun word nie. Die verpleegkundige se observasies is eweneens van belang. Volgens Bagley en sy kollegas (1982:192) moet sy, afgesien van die tekens van simpatiese en parasimpatiese stimulasie, ook bedag wees op ander, dikwels vae tekens soos moegheid en onvermoë om te ontspan, wat ook mag dui op pyn.

Die beraming van die intensiteit van 'n pasiënt se pyn behoort in enige beramingsinstrument belangrik te wees (Daut en Cleeland 1982:1913, 1914). In die beraming word van twee metodes gebruik gemaak. Die eerste metode is ' $n$ verbale metode waarvolgens die pasiënt gevra word of sy geen pyn, min pyn, matige pyn of erge pyn ervaar (Hillier 1987:1646, Ruoff en Beery 1985:93, Heidrich en Perry 1982:1828). Van die pasiënt word dan verwag om een van die moontlikhede uit te wys as die mees beskrywende van die pyn wat sy ervaar. In die tweede metode word gebruik gemaak van beskrywende skale wat aan die pasiënt verskaf word, waarop sy dan die posisie op die skaal identifiseer wat volgens haar die meeste ooreenstem met die pyn wat sy ervaar (Bagley et.al. 1982:193). Drie tipes beskrywende skale kan onderskei word. Die eenvoudige beskrywende skaal bestaan uit ' $n$ reguit horisontale lyn waaronder die moontlike grade van intensiteit in woorde beskryf word(Fig.1)(Bagley et.al. 1982:193).

\begin{tabular}{llllc}
\hline geen & min & matig & erge & ondraaglike \\
pyn & pyn & pyn & pyn & pyn
\end{tabular}

Figuur 1 Eenvoudige beskrywende skaal vir pynevaluering

By die numeriese skale (Fig. 2) kan die pasiënt haar pyn in numeriese waardes uitdruk (Donovan 1982:717, Bagley et.al. 1982:193).

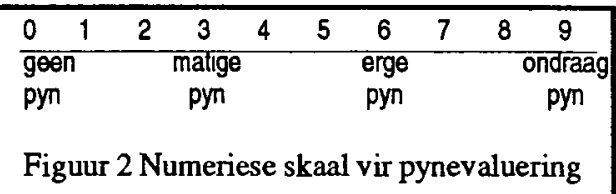

Die derde tipe beskrywende skale is die visuele analogie skale (Fig. 3) waarop net die twee uiterstes van pynintensiteit naamlik geen pyn en ondraaglike pyn op die skaal aangebring is. Die pasiënt dui 'n punt op die skaal aan om die intensiteit van die pyn wat sy ervaar aan te dui (Bagley et.al. 1982:193, Ruoff en Beery 1985:93, Fishman et.al. 1987:1152).

\begin{tabular}{|c|c|}
\hline geen & ondraaglike \\
\hline pyn & pyn \\
\hline
\end{tabular}

Die ligging van die pyn kan deur die pasiënt alleen verstrek word en is eweneens belangrik in die beraming van pyn (Dugan 1984:286). Daar kan van drie metodes gebruik gemaak word om die ligging van die pyn te identifiseer. In die eerste metode word die liggaam in streke verdeel, naamlik die kop, gesig, nek, borskas, arms, abdomen, rug, bene, pelvis en perineum en aan die pasiënt voorgehou sonder ' $n$ visuele voorstelling van die liggaam. Die pasiënt dui dan die streek aan waarin sy pyn ervaar (Bagley et.al. 1982:194). In die tweede metode word 'n skematiese voorstelling van die liggaam (Fig. 4) aan die pasiënt verskaf waarop sy dan die ligging sowel as die verspreiding van die pyn wat sy ervaar aandui (Van der Westhuizen en Vermaak 1984:191). Volgens die derde metode toon die pasiënt op haar eie liggaam die ligging en verspreiding van die pyn wat sy ervaar aan (Donovan 1982:717).

'n Volledige beskrywing van die aard van die pyn wat 'n pasiënt ervaar is 'n belangrike deel van die beraming van die pyn (Dugan 1984:286). Cleeland haal 'n studie $v$ an Schwettman en sy kollegas aan wat toon dat die beskrywing van pyn deur die pasiënt nie maar net subjektief en niksseggend is nie. In die studie is 'n groot ooreenkoms gevind tussen die beskrywing van pyn en die onderliggende oorsaak. Pasiënte met beenpyn het die meeste gebruik gemaak van die beskrywende woorde 'kloppende pyn', pasiënte met pyn veroorsaak deur sagteweefselskade van 'steekpyn' en pasiënte met behandelingverwante pyn van 'teerheid' en 'brandende pyn' (Cleeland 1984:2638).

Die duur van die pyn is eweneens van belang (Dugan 1984:286, Van der Westhuizen en Vermaak 1984:191), soos ook die gebeure met die aanvang van pyn en die vorige ervaring met betrekking tot pyn wat ook die faktore wat pyn verlig of vererger insluit (Dugan 1984:286). Spesifieke faktore wat pyn mag verlig of vererger word deur Donovan (1982:717) verstrek. Hierdie faktore is volgens haar aktiwiteit, eet, spanning, vrese, eensaamheid, besoek deur gesinslede, familielede en vriende en prosedures insluitend verpleegprosedures.

\section{Bevindinge uit literatuuroorsig}

\section{Die volgende bevindinge is verkry:}

- Alle pasiënte met karsinoom ervaar nie noodwendig pyn nie. Pyn kom egter wel voor. Sekere tipes karsinoom word meer dikwels met pyn verbind as ander tipes. 

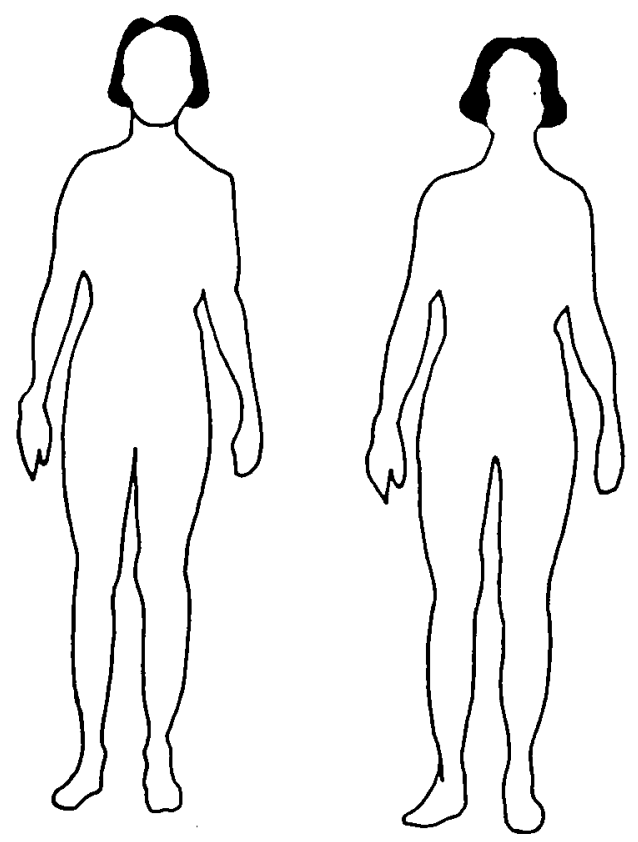

Figuur 4 Skematiese voorstelling van die liggaam

- Chroniese pyn word meer met karsinoom geassosieer as akute pyn.

- Pyn word nie net met gevorderde karsinoom ervaar nie. Dit kan ook met die aanvang van karsinoom ervaar word.

- Somatiese, viserale en neurogene pyn kom voor. Metastasering is dikwels die oorsaak daarvan.

- Die onkologiese proses is die grootste oorsaak van pyn by pasiënte met karsinoom.

- Pasiënte met karsinoom ervaar ook pyn wat nie aan die onkologiese proses of die behandeling verbind kan word nie. Konstipasie, ulkusse, spierspasmas en absesse is dikwels oorsake van pyn.

- Die pyn wat pasiënte met karsinoom ervaar kan volgens die oorsake geklassifiseer word as akute of chroniese karsinoom-verwante pyn en reeds bestaande chroniese pyn gekombineer met karsinoom-verwante pyn en karsinoom-verwante pyn in die terminale fase van siekteverloop.

- Omdat pynimpulse via C-vesels en A-deltavesels gelei word, ervaar die pasiënte eers 'n skerp gelokaliseerde sensasie wat gevolg word deur 'n dowwe, kloppende difuse pyngevoel. Dit staan ook bekend as vinnige en stadige, of eerste en tweede pyn.

- Die substantia gelatinosa is besonder betrokke by pynimpuls-geleiding omdat beide die A-delta en C-vesels hier sinapse vorm. Dit is egter ook betrokke by geleiding van ander tipes impulse. Groter afferente senuvesels as die A-delta en C-vesels vorm hier sinapse. Wanneer die geleiding van impulse in die groter senuvesels gestimuleer word, aktiveer dit die substantia gelatinosa tot so 'n mate dat dit die geleiding van enige ander impulse, insluitend pynimpulse teenstaan. So sal massering van 'n pynlike area, waarvandaan die impulse met groter afferente vesels gelei word na die substantia gelatinosa die 'hek sluit' sodat die pynimpulse nie gelei word nie.

- Die geleiding van pynimpulse in die spinotalamiese bane word deur serotonien beheer. Stress beïnvloed die vrystelling van serotonien.

- Endorfien beïnvloed pynpersepsie. Dit inhibeer oor die oordrag van pynimpulse.

- Ter wille van effektiewe pynverligting behoort pyn vroeg opgespoor en beraam te word.

- Omdat pyn 'n subjektiewe ervaring is, speel verskeie faktore ' $n$ rol in pasiënte se persepsie van pyn. Fisieke, psigologiese en sosiokulturele faktore beïnvloed pynpersepsie.

- Pasiënte behoort in die beraming van pyn betrokke te wees. Net die pasiënte alleen weet hoe erg die pyn wat hulle ervaar, is.

- Pasiënte met chroniese pyn gee nie altyd uitdrukking daaraan nie. Hulle ontwikkel eerder meganismes om die intensiteit daarvan te verminder. Daar kan dus in die beraming van pyn nie net op die pasiënte se interpretasie en verbalisering gesteun word nie. Die verpleegkundige se observasies is eweneens van belang.

\section{GEVOLGTREKKING}

Hoewel nie almal nie, ervaar 'n groot persentasie van pasiënte met karsinoom om verskeie redes pyn. Omdat pyn 'n unieke subjektiewe ervaring is, behoort nie alleen die oorsake nie, maar ook die pasiënte se ervaring van die pyn, in die beraming daarvan verreken te word. Volledige en tydige beraming is nodig om effektiewe verpleegtussentredes ter pynverligting moontlik te maak.

\section{AANBEVELINGS}

Die bevindinge van hierdie studie kan met vrug in die pynverligting van pasiënte met karsinoom gebruik word, deur op die volgende te let:

- Pasiënte met karsinoom ervaar dikwels chroniese pyn wat hulle nie goed verbaliseer nie. Intensiewe beraming is dus nodig.

- Farmakologiese pynverligting is maar een aspek van pynverligting. Verskeie verpleegtussentredes wat berus op die stimulering van die substantia gelatinosa kan effektief in die verligting van pyn aangewend word. Die ondersteuning van pasiënte en die gepaardgaande vermindering van die stres is ook pynverligtend deurdat dit verminderde serotonienvrystelling teenwerk.

\section{BIBLIOGRAFIE}

ANDERSON, J.L. 1982. Nursing management of the cancer patient in pain: A review of the literature. Cancer Nursing, $5,33-41$

BAGLEY, C.S., FALINSKI, E., GARNIZO, N. \& HOOKER, L. 1982. Pain management: A pilot project. Cancer Nursing, 5, 191-199.

BOOKER, J.E. 1982. Pain it's all in your patient's head (or is it?). Nursing 82 , 12(3):47-51.

BURNS, N. 1982. Nursing and cancer. London: W.B. Saunders Co.

CAMP, L.D. \& O'SULLIVAN, P.S. 1987. Comparison of medical, surgical and oncology patients' descriptions of pain and nurses' documentation of pain assessment. Journal of Advanced Nursing, 12(5):593-598.

CLEELAND, C.S. 1984. The impact of pain on the patient with cancer. Cancer, 54(11):2635-2641.

COYLE, N. 1987. A model of continuity of care for cancer patients with chronic pain. Medical Clinics of North America, 71(2):259-270. 
CUMMINGS, D. 1981. Pain. Nursing 81, 11(1):60-62.

DAUT, R.L. \& CLEELAND, C.S. 1982. The prevalence and severity of pain in cancer. Cancer, 50(9): 1913-1918.

DAVIS, P. 1985. Positive pain relief. Nursing Mirror, 161(11):36-40.

DONOVAN, M. 1982. Cancer pain: You can help! Nursing Clinics of North America, 17(4):713-727.

DUGAN, S.O. 1984. Pain. In Cancer Nursing: a Developmental approach. Ed. by McIntire, S.N. and Cioppa, A.L. New York: John Wiley and Sons, 277-303.

FISHMAN, B. et.al. 1987. The memorial pain assessment card: A valid instrument for the evaluation of cancer pain. Cancer, 60(5):1151-1158.

FOLEY, K.M. 1985. The Treatment of cancer pain. The New England Journal of Medicine, 313(2):84-95.

HEIDRICH, G. \& PERRY, S. 1982. Helping the patient in pain. American Journal of Nursing, 82(12):1829-1833.

HILLIER, R. 1987. Pharmacological management of pain in advanced cancer. Medicine International - South African Student Edition, 2(3):1645-1648.

HOLMES, P. 1987. Breaking the pain barrier. Nursing Times, 83(6):51-52.

JACOX, A.K. 1979. Assessing Pain. American Journal of Nursing, 79(5):895-900.

KORI, S.H., FOLEY, K.M. \& POSNER, J.B 1981. Brachial plexus lesions in patients with cancer: 100 cases. Neurology, $31(1): 45-50$.

LIPMAN, A.G. 1980. Drug therapy in cancer pain. Cancer Nursing, 3:39-46.
MASSIE, M.J. \& HOLLAND, J.C. 1987. The cancer patient with pain: Psychiatric complications and their management. Medical Clincs of North America, 71(2):243-257.

MCCAFFERY, M. 1990. Nursing approaches to nonpharmacological pain control. International Journal of Nursing Studies, 27(1):1-5.

MOCAFFERY, M. 1990. Pain management. Nurses lead the way to new priorities. American Journal of Nursing, 90(10):45-48.

MEIJ, H.S. \& MEYHER, B.J. 1979. Reseptore, afferente sensoriese geleidingstelsels en algemene gewaarwordings. In Die fisiologiese basis van geneeskunde. Red. Meyer, B.J. Tweede Hersiene Uitgawe. Pretoria: HAUM Uitgewery, 13.1-10.

MEYER, B.J. 1979. Hipotalamus-hipofise-as: Hipotalamushormone. In Die Fisiologiese basis van geneeskunde. Red. Meyer, B.J. Tweede Hersiene Uitgawe. Pretoria: HAUM Uitgewery, 57.1-9.

MOSELEY, J.R. 1985. Alterations in comfort. Nursing Clinics of North America, 20(2):427-439.

MULLER, R.A. \& PELCZYNSKI, L. 1982. You can control cancer pain with drugs but the proper way may surprise you. Nursing $82,12(6): 50-57$.

PAYNE, R. \& FOLEY, K. 1986. Exploration of the brachial plexus in patients with cancer. Neurology, 36(4), Supplement, 329.

PAYNE, R. 1987. Anatomy, physiology and neuropharmacoloy of cancer pain. Medical Clinics of North America, 71(2):153-167.

perkin, g.d. 1987. Neurological complications of malignancy. Medicine International: South African student edition, 2(3):1634-1636.
RUOFF, G.E. \& BEERY, G.B. 1985. Chronic pain: Characteristics, assessment, and treatment plans. Postgraduate Medicine, 78(4):91-96.

SNYDER, C.C. 1986. Oncology Nursing. Boston: Little, Brown and Company.

SPIEGEL, D. \& BLOOM, J.R. 1983. Pain in metastatic breast cancer. Cancer, 52(2):341-345.

VAN DER WESTHUIZEN, S.J.C. \& VERMAAK M.V. 1984. Behoefte aan gemak. In Verpleegkunde: Menslike, wetenskaplike gesondheidsorg. Red. Uys, L.R. en Mulder, M. Pretoria: HAUM Opvoedkundige Uitgewery, 171-196.

VAN WYK, N.C. 1987. Die onkologiese behandelingsbenadering. In Algemene Verpleegkunde: Mediese en chirurgiese handleiding. Deel 2. Red. Viljoen, M.J. en Uys, L.R. Pretoria: HAUM Opvoedkundige Uitgewery: 208-242.

WAINWRIGHT, P. 1985. Impact of hospital architexture on the patient in pain. In Perpectives on Pain. Ed. by Copp, L.A. London: Churchill Livingstone, 46-61.

WEST, B.A. 1981. Pain. Nursing 81, February, 51-53.

WILSON, R.W. \& ELMASSIAN, B.J. 1981. Endorphins. American Journal of Nursing, April, 722-725.

YOUNG, J.L. 1977. The pain of a terminally ill patient in the home. Nursing Clinics of North America, 12(4):653-662.

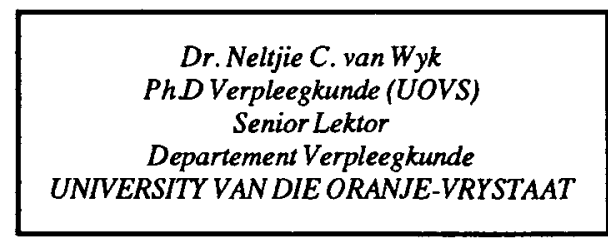

